\title{
Host-Parasite Relationships in Porcine Ascariosis: Anticoagulant Potential of the Third Larval Stage of Ascaris suum as a Possible Survival Mechanism
}

\author{
Alicia Diosdado ${ }^{1}$, Fernando Simón ${ }^{1}$, Rodrigo Morchón ${ }^{1}$ (D) and Javier González-Miguel ${ }^{2, *(D)}$ \\ 1 Animal and Human Dirofilariosis Group, Laboratory of Parasitology, Faculty of Pharmacy, \\ University of Salamanca, C/Licenciado Méndez Nieto s/n, 37007 Salamanca, Spain; alidm@usal.es (A.D.); \\ fersimon@usal.es (F.S.); rmorgar@usal.es (R.M.) \\ 2 Laboratory of Parasitology, Institute of Natural Resources and Agrobiology of Salamanca (IRNASA-CSIC), \\ C/Cordel de Merinas 40-52, 37008 Salamanca, Spain \\ * Correspondence: jglez@usal.es
}

Citation: Diosdado, A.; Simón, F.; Morchón, R.; González-Miguel, J. Host-Parasite Relationships in Porcine Ascariosis: Anticoagulant Potential of the Third Larval Stage of Ascaris suum as a Possible Survival Mechanism. Animals 2021, 11, 804. https://doi.org/10.3390/ani11030804

Academic Editor: Pablo Diaz

Received: 19 February 2021

Accepted: 10 March 2021

Published: 13 March 2021

Publisher's Note: MDPI stays neutral with regard to jurisdictional claims in published maps and institutional affiliations.

Copyright: (c) 2021 by the authors. Licensee MDPI, Basel, Switzerland. This article is an open access article distributed under the terms and conditions of the Creative Commons Attribution (CC BY) license (https:// creativecommons.org/licenses/by/ $4.0 /)$.
Simple Summary: Ascaris suum parasitises pigs all over the world causing a disease responsible for producing reductions in weight gains and damages to several organs of the infected animals that incur huge economic losses for the swine industry. While adult worms of this parasite are located in the small intestine of the host, their larval stages migrate through the bloodstream as an evolutionary advantageous strategy within a hostile environment that confronts host responses such as blood clots formation. The aim of this work is to study the ability of A. suum larvae to inhibit blood coagulation as a possible mechanism to control blood clots formation and facilitate their migration. The results showed that these larvae inhibited host blood coagulation and possessed molecules similar to those responsible for inhibiting blood coagulation in pigs. The anticoagulant effect of $A$. suum larvae could constitute a potential survival mechanism for the parasite. Therefore, developing new control strategies directed at this and similar processes could avoid A. suum larval migration and the establishment of adult worms in their definitive location, which is necessary to confront the damages and economic losses produced by this parasitosis.

Abstract: In order to evade the response of their hosts, helminth parasites have evolved precise and highly regulated mechanisms, including migration strategies of the larval stages. In regard to porcine ascariosis caused by Ascaris suum, its infective third-stage larvae (AsL3) undergo a complex migratory route through the bloodstream of their host before establishing in the small intestine to reach maturation. Despite the benefits attributed to this migration, blood clots formation could compromise larvae survival. The aim of this work was to study the interaction between the cuticle and excretory/secretory antigens of AsL3 and the host coagulation cascade. Larvae were obtained after incubating and hatching $A$. suum eggs, after which the antigenic extracts were produced. Their ability to disrupt the coagulation cascade was studied using anticoagulation and chromogenic assays, and techniques based on electrophoresis. The obtained results showed that both antigenic extracts possessed anticoagulant potential, being able to inhibit the intrinsic, extrinsic and/or common pathways of the blood coagulation cascade as well as the activated factor X. Moreover, three A. suum serpin proteins were identified as candidates to inhibit this host coagulation factor. To the best of our knowledge, this study shows, for the first time, the anticoagulant potential of the infective larvae of A. suum, which could be used by the parasite as a mechanism to facilitate its invasion and survival in the host.

Keywords: Ascaris suum; third-stage larvae; coagulation cascade; anticoagulant; factor Xa; serpin; larval migration; ascariosis; host-parasite relationships 


\section{Introduction}

The beginning of the relationship between pigs and humans dates back thousands of years to when domestication of pigs occurred [1]. Since then, this species has become the main source of meat for human consumption, with the swine industry being the largest producer of meat in the world and an important economic driver in many regions $[2,3]$. Nevertheless, this industry suffers from significant economic losses, owing to the diseases affecting pigs, among which are soil-transmitted helminthiasis that are easily spread through the faecal-oral route. The most prevalent of these parasites with a worldwide distribution is the causal agent of porcine ascariosis, Ascaris suum [4]. Its infective thirdstage larvae (AsL3) carry out a complex migratory route through the host tissues before reaching maturation and establishing in the host small intestine. Briefly, AsL3 hatch from ingested eggs in the small intestine and migrate to the caecum and proximal colon to penetrate the mucosa. Then, larvae reach the liver through the hepatic portal system, after which they are carried to the lungs via the systemic circulation. There, AsL3 abandon the circulatory system penetrating the alveolar space to ascend the trachea, reach the oesophagus and return to the small intestine to complete maturation [5]. Once there, adult worms produce growth reduction of infected pigs, but the most severe damages in porcine ascariosis are due to the passage of larvae through the liver and lungs. Both affect animal welfare and are responsible for the huge economic losses, which are directly related to porcine ascariosis [4]. In spite of its importance, optimal diagnostic methods for this parasitosis are not available, and control tools rely on the use of anthelmintic drugs, which entail serious drawbacks that could be improved with the development of vaccination strategies [6]. In order to achieve this purpose, unravelling the molecular basis of the host-parasite relationships in porcine ascariosis is of paramount importance, mainly during the early stages of the infection $[7,8]$.

One of the most striking mechanisms governing host-parasite relationships is the ability of some parasites to manipulate the haemostatic system of their mammalian hosts, including blood coagulation and the fibrinolytic system, which has been related to their success in both the invasion process and their survival inside the host [9-12]. Blood coagulation is a complex mechanism necessary to stop the haemorrhage when a vascular injury occurs, and includes primary (activation and aggregation of platelets) and secondary (the coagulation cascade) haemostasis. Both mechanisms culminate with the formation of a stable clot between platelets and the cross-linked fibrin deposited over them. Fibrin is the protein responsible for stabilizing the clot and the resultant product of the coagulation cascade, a series of enzymatic chain reactions in which different zymogens (coagulation factors) are activated in their catalytically active serine proteases [13]. The coagulation cascade is divided into two different pathways (intrinsic and extrinsic) that converge at a common point with the activation of factor X (FXa), which participates in thrombin formation, the protein responsible for transforming fibrinogen into fibrin [14]. The regulation of the coagulation cascade depends on the action of several inhibitors, among them antithrombin is the most quantitatively important because it is able to exert its activity against all serine proteases participating in the coagulation process. Antithrombin belongs to the group of serpins (serin protease inhibitors) [15], a noteworthy superfamily of enzymes due to its high evolutionary conservation between mammals and nematodes [16] and its action mechanism based on the formation of a stable complex with its target protein [17].

In a previous study, we have recently demonstrated the capacity of the cuticle and excretory/secretory antigenic extracts of AsL3 (AsL3C and AsL3ES) to activate the host fibrinolytic system, which represents the mechanism of the haemostatic system responsible for dissolving blood clots [18]. In order to complement this study and contribute to the knowledge of the host-parasite relationships in porcine ascariosis, the present work was carried out with the aim of evaluating the ability of AsL3C and AsL3ES to inhibit the coagulation cascade of the host as a potential survival mechanism. 


\section{Materials and Methods}

\subsection{Collection of Third-Stage Larvae of A. suum}

AsL3 were obtained, as previously described [19], with minor modifications. Adult female A. suum worms were collected from naturally infected pigs from a local abattoir. Parasites were dissected to extract the uterus and both worms and uteri were washed with phosphate-buffered saline (PBS) $\left(0.15 \mathrm{M} \mathrm{NaCl}, 0.03 \mathrm{M} \mathrm{NaH}_{2} \mathrm{PO}_{4} \mathrm{H}_{2} \mathrm{O}, 0.08 \mathrm{M} \mathrm{Na}_{2} \mathrm{HPO}_{4}\right.$, $\mathrm{pH}$ 7.2). A. suum eggs were extracted from the uterus, washed with PBS, suspended in a $2 \%$ $(w / v)$ potassium dichromate $\left(\mathrm{K}_{2} \mathrm{Cr}_{2} \mathrm{O}_{7}\right)$ solution and cultured in 24-well plates (Corning, New York, NY, USA) to be incubated at $27^{\circ} \mathrm{C}$ for approximately 40 days in a place restricted from light. Once most eggs had embryonated, they were transferred from culture plates to test tubes (Falcon, New Jersey, NJ, USA). The potassium dichromate solution was removed and the eggs were treated with $5-6 \%(w / v)$ sodium hypochlorite $(\mathrm{NaClO})$ (commercial bleach) at $37^{\circ} \mathrm{C}$ for $15 \mathrm{~min}$. After washing at least 5 times with PBS by centrifugation at $200 \times g$ for $5 \mathrm{~min}$, the eggs were transferred into an Erlenmeyer flask containing glass beads and a magnetic stir bar to be shaken slowly $(60 \times r p m)$ for approximately $1 \mathrm{~h}$. Once most larvae had hatched, the suspension was poured into a cotton gauze layer $(2.5 \mathrm{~g})$ on a Baermann apparatus filled with PBS following the protocol described by Urban et al. [20]. After being cultured at $37{ }^{\circ} \mathrm{C}$ in a humidified atmosphere in the presence of $5 \% \mathrm{CO}_{2}$ overnight, AsL3 were collected from the neck of the funnel and washed with PBS to be subsequently used to obtain the antigenic extracts.

\subsection{Collection of Antigenic Extracts from AsL3 and Porcine Plasma Samples}

AsL3C and AsL3ES antigenic extracts were prepared according to the methodology described by Wedrychowicz et al. [21] and González-Miguel et al. [22], respectively, with minor modifications. To isolate the cuticle antigens, AsL3 were incubated in a $0.25 \%(w / v)$ cetyl trimethyl ammonium bromide (CTAB) solution at $37^{\circ} \mathrm{C}$ for $4 \mathrm{~h}$ shaking, after which larvae were removed by centrifugation at $200 \times g$ for $5 \mathrm{~min}$. The supernatant was filtered through a filter of $0.22 \mu \mathrm{m}$ (Millex, Carrigtwohill, Ireland) and proteins were precipitated with a solution of $0.002 \mathrm{M}$ sodium acetate and 9 volumes of $96 \%$ ethanol at $-20{ }^{\circ} \mathrm{C}$ for $48 \mathrm{~h}$. The suspension was centrifuged at $10,000 \times \mathrm{g}$ for $10 \mathrm{~min}$ and the resultant pellet was re-suspended in PBS. In order to obtain de excretory/secretory antigens, the same quantity of AsL3 was cultured in RPMI-1640 medium (Sigma-Aldrich, Saint Louis, MO, USA) supplemented with a $1 \%(v / v)$ antibiotic-antimycotic solution $(100 \times)$ (Sigma-Aldrich) at $37{ }^{\circ} \mathrm{C}$ and $5 \% \mathrm{CO}_{2}$ for $24 \mathrm{~h}$. After removing larvae by centrifugation at $200 \times g$ for $5 \mathrm{~min}$, the medium was filtered through a filter of $0.22 \mu \mathrm{m}$ (Millex). The suspension was dialyzed against water at $4{ }^{\circ} \mathrm{C}$ for $48 \mathrm{~h}$ shaking and then proteins were concentrated using Amicon Ultra-15 centrifugal filter devices (Millipore, Burlington, VT, USA). Lastly, a cocktail of proteases inhibitors [23] was added to both antigenic extracts. AsL3C and AsL3ES protein concentrations were measured by the BCA protein assay reagent kit (Thermo Fisher Scientific, Waltham, MA, USA) and both antigenic extracts were subsequently stored at $-80{ }^{\circ} \mathrm{C}$ until their use.

Blood samples were collected from pigs from a local abattoir in tubes containing sodium citrate (0.106 M, 3.8\%) (Aquisel, Barcelona, Spain). Samples were immediately centrifuged after collection at $1500 \times g$ for $15 \mathrm{~min}$ to separate plasma from blood cells. Plasma samples were stored at $-80^{\circ} \mathrm{C}$ until used.

\subsection{Anticoagulation Assays}

The anticoagulant activity of AsL3C and AsL3ES on the host coagulation cascade was assayed following the protocol described by Gan et al. [24] with some modifications. The intrinsic and extrinsic pathways of the coagulation cascade were studied by the activated partial thromboplastin time (APTT) and the prothrombin time (PT) assays, respectively. Both assays also allowed us to study the common pathway of the coagulation cascade. The conversion of fibrinogen into fibrin was evaluated by the thrombin time (TT) assay. The APTT assay was performed by coating multi-well microplates (Corning) with $0.5 \mu \mathrm{g}$ 
per well of AsL3C or AsL3ES in the presence of $50 \mu \mathrm{L}$ of plasma and $50 \mu \mathrm{L}$ of APTT reagent (BioSystems, Barcelona, Spain). After incubating at $37^{\circ} \mathrm{C}$ for $3 \mathrm{~min}, 50 \mu \mathrm{L}$ of $\mathrm{CaCl}_{2}$ (BioSystems) were added to the previous mixtures to initiate the clotting reaction. For the PT assay, $0.5 \mu \mathrm{g}$ per well of AsL3C or AsL3ES were incubated with $50 \mu \mathrm{L}$ of plasma at $37^{\circ} \mathrm{C}$ for $2 \mathrm{~min}$. Then, $100 \mu \mathrm{L}$ of PT reagent (BioSystems) were added to initiate the clotting reaction. Finally, in order to perform the TT assay, $0.5 \mu \mathrm{g}$ per well of each antigenic extract were incubated with $100 \mu \mathrm{L}$ of plasma at $37^{\circ} \mathrm{C}$ for $2 \mathrm{~min}$, after which the clotting reaction was initiated with $100 \mu \mathrm{L}$ of TT reagent (BioSystems). Clotting reactions were monitored by measuring the absorbance at $655 \mathrm{~nm}$ every $6 \mathrm{~s}$ during a period of $42 \mathrm{~s}$ in a Microplate Absorbance Reader iMark (Bio-Rad, Hercules, CA, USA). Frozen plasma and reagents were, respectively, thawed and brought to $37^{\circ} \mathrm{C}$ just prior to use. PBS was used as a negative control. Each sample was analysed in triplicate.

\subsection{FXa Inhibition Assay}

To evaluate the inhibitory activity of AsL3C and AsL3ES against FXa, a chromogenic assay was performed, as previously described [24], with some modifications. In a final volume of $100 \mu \mathrm{L}, 0.1 \mu \mathrm{g}$ per well of each antigenic extract were incubated with the native human FXa (Thermo Fisher Scientific) at a final concentration of $4 \mathrm{nM}$ in 4-(2-hydroxyethyl)1-piperazineethanesulfonic acid (HEPES)-BSA buffer (50 mM HEPES, pH 7.5, $100 \mathrm{mM}$ $\mathrm{NaCl}, 5 \mathrm{mM} \mathrm{CaCl}, 1 \mathrm{mg} / \mathrm{mL}$ BSA) in multi-well microplates (Corning) at $37^{\circ} \mathrm{C}$ for $15 \mathrm{~min}$. The chromogenic substrate S-2765 of FXa (Chromogenix, Bedford, MA, USA) was then added at a final concentration of $800 \mu \mathrm{M}$ and incubated at $37^{\circ} \mathrm{C}$ for $3 \mathrm{~h}$. The hydrolysis of the substrate was monitored by measuring the absorbance at $415 \mathrm{~nm}$ every $30 \mathrm{~min}$ in a Microplate Absorbance Reader iMark (Bio-Rad). PBS was used as a negative control. Each sample was analysed in triplicate.

\subsection{Binding of AsL3C and AsL3ES to FXa}

In order to determine the likely capacity of AsL3C and AsL3ES proteins to trap FXa into a stable complex, a sodium dodecyl sulfate polyacrylamide gel electrophoresis (SDSPAGE) was carried out according to the method described by Fonseca et al. [25] with some modifications. Samples of $10 \mu \mathrm{g}$ of the antigenic extract (AsL3C or AsL3ES), $1 \mu \mathrm{g}$ of the FXa and a mixture of both compounds (antigenic extract and FXa) were incubated in $5 \mathrm{mM}$ HEPES buffer, $\mathrm{pH}$ 7.4, at room temperature for $45 \mathrm{~min}$. All samples were loaded into 10\% polyacrylamide gels and protein bands were detected by silver staining after finishing the electrophoresis. Gels were scanned with the GS-800 Densitometer (Bio-Rad). All assays were performed in triplicate.

\subsection{Mass Spectrometry, Protein Identification and Bioinformatic Analyses}

Selected bands containing potential FXa-AsL3 protein complexes were manually excised from the gels and analysed by liquid chromatography and tandem mass spectrometry (LC-MS/MS) at the proteomics facility of the Servei Central de Suport a la Investigació Experimental (SCSIE) of the University of Valencia, Spain. Samples were digested with sequencing grade trypsin (Promega, Madison, WI, USA) (50 ng) [26] and the resultant digestion mixture was dried in a vacuum centrifuge and re-suspended in $7 \mu \mathrm{L} 2 \%(v / v)$ acetonitrile $(\mathrm{ACN}), 0.1 \%(v / v)$ trifluoroacetic acid (TFA). Five microliters of each sample were loaded onto a trap column (NanoLC Trap, ChromXP, C18-CL $3 \mu \mathrm{m}, 120 \AA, 350 \mu \mathrm{m}$ $\times 0.5 \mathrm{~mm})($ Eksigent Technologies, Framingham, MA, USA) and desalted with $0.1 \%(v / v)$ TFA at $3 \mu \mathrm{L} / \mathrm{min}$ during $5 \mathrm{~min}$. Peptides were then loaded onto an analytical column (NanoLC Column, 3 C18-CL-120, $3 \mu \mathrm{m}, 120 \AA$, $75 \mu \mathrm{m} \times 15 \mathrm{~cm}$ ) (Eksigent Technologies) equilibrated in $5 \%(v / v) \mathrm{ACN}, 0.1 \%(v / v)$ formic acid (FA). Elution was carried out with a linear gradient of 30\% $(v / v)$ B in A [A: $0.1 \%(v / v)$ FA; B: ACN, $0.1 \%(v / v)$ FA] for $20 \mathrm{~min}$ at a flow rate of $300 \mathrm{~nL} / \mathrm{min}$. Peptides were analysed in a mass spectrometer nano-ESI-QqTOF (5600 TripleTOF) (AB Sciex, Framingham, MA, USA) and each sample was ionized in a Source Type Optiflow $<1 \mu \mathrm{L}$ Nano applying $3.0 \mathrm{kV}$ to the spray emitter at $200{ }^{\circ} \mathrm{C}$. Anal- 
yses were carried out in a data-dependent mode. Survey MS1 scans were acquired from $350-1400 \mathrm{~m} / z$ for $250 \mathrm{~ms}$. The quadrupole resolution was set to LOW for MS2 experiments, which were acquired from $100-1500 \mathrm{~m} / \mathrm{z}$ for $25 \mathrm{~ms}$ in high sensitivity mode. The following switch criteria were used: charge $2+$ to $4+$, minimum intensity and 250 counts per second. Up to 100 ions were selected for fragmentation after each survey scan. Dynamic exclusion was set to $15 \mathrm{~s}$. The system sensitivity was controlled by analysing $0.5 \mu \mathrm{g}$ of K562 trypsin digestion (SCIEX, Framingham, USA). ProteinPilot (SCIEX) default parameters were used to generate peak list directly from 6600 plus TripleTOF files. The Paragon algorithm [27] of ProteinPilot v 5.0 was used to search for in the Swiss-Prot and UniProt_Nematoda databases with the following parameters: trypsin specificity, cys-alkylation, taxonomy non-restricted and search effort set to through with FDR analyses. The protein grouping was done by the Pro group algorithm.

The amino-acid sequences of the interesting proteins for the study resulting from the LC-MS/MS analyses were analysed using the following bioinformatic tools: BLAST searching of the homologous sequences in the NCBI and Swiss-Prot/UniProt databases (http://www.ncbi.nlm.nih.gov/, http://www.uniprot.org/), analysis of conserved protein domains with Prosite (https://prosite.expasy.org/), prediction of signal peptides with SignalP-5.0 [28] (http:/ / www.cbs.dtu.dk/services/SignalP) and multiple sequence alignment with Clustal Omega (https://www.ebi.ac.uk/Tools/msa/clustalo/) (accessed on 4 November 2020 for all websites).

\subsection{Statistical Analysis}

Anticoagulation assays and FXa inhibition assay results were analysed with the Student's $t$-test. Data were expressed as the mean \pm standard deviation (SD) of three independent experiments. Significant differences were defined as a $p$-value of $<0.05$ for a confidence level of $95 \%$.

\section{Results}

\subsection{AsL3C and AsL3ES Possess Anticoagulant Activity}

The anticoagulant activity of AsL3C and AsL3ES was evaluated by the anticoagulation assays APTT, PT and TT. The results of APTT and PT assays showed that both antigenic extracts possessed anticoagulant activity, since their optical densities were significantly lower than those obtained for the negative controls over time $(p<0.05)$. No significant differences were found between groups for both antigenic extracts in the TT assay $(p<0.05)$ (Figure 1).

\subsection{AsL3C and AsL3ES Inhibit FXa}

The inhibitory activity of AsL3C and AsL3ES against FXa was studied by a chromogenic assay. Optical densities were significantly lower for AsL3C and AsL3ES extracts than those obtained for the negative controls, which showed the inhibitory properties of both antigenic extracts against FXa over time $(p<0.05)$ (Figure 2).

\subsection{AsL3C and AsL3ES Bind FXa}

To evaluate whether AsL3C and AsL3ES were able to trap FXa into a stable complex, a SDS-PAGE was performed. The electrophoresis gel revealed that both antigenic extracts bound FXa since two bands in the lanes containing the pre-incubated mixture of AsL3C/AsL3ES and FXa appeared in a larger molecular weight ( 31 and $\sim 34 \mathrm{kDa})$ than in the lanes containing only the coagulation factor, in which they were respectively located at $\sim 29$ and $\sim 32 \mathrm{kDa}$. These bands were absent in the lanes containing only the antigenic extracts (Figure 3 ). In addition, other changes were observed in the electrophoresis gel. In the case of AsL3C, bands between $\sim 23$ and $\sim 28 \mathrm{kDa}$ and those located under $20 \mathrm{kDa}$ in the sample prepared only in the presence of the antigenic extract were, respectively, absent and less stained in the pre-incubated mixture. With respect to AsL3ES, two bands (at 21.9 and 
$23.1 \mathrm{kDa}$ ) located in the pre-incubated mixture were, respectively, absent and less stained in the sample prepared only in the presence of the antigenic extract (Figure 3).
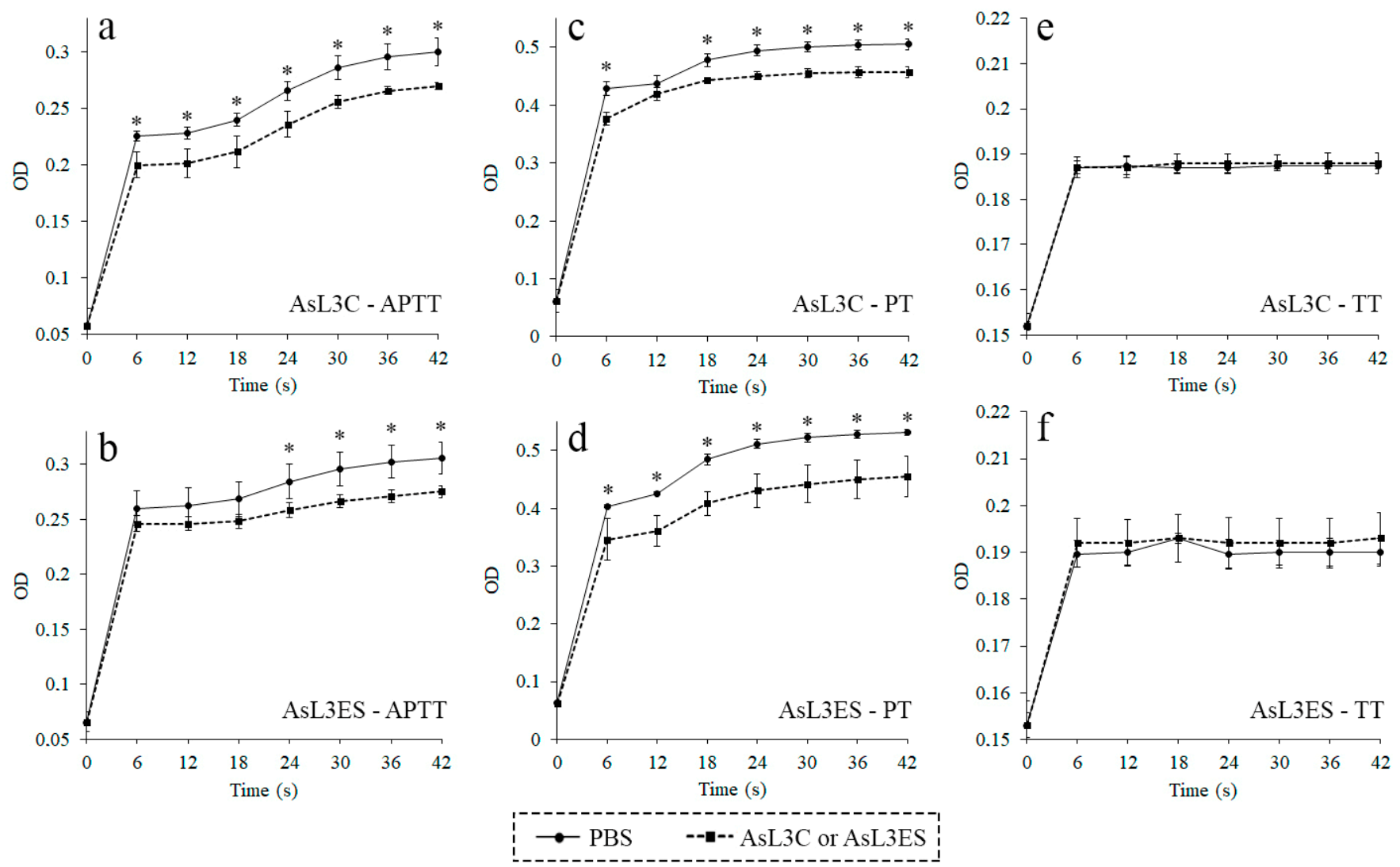

Figure 1. Anticoagulant activity of AsL3C $(\mathbf{a}, \mathbf{c}, \mathbf{e})$ and AsL3ES $(\mathbf{b}, \mathbf{d}, \mathbf{f})$ evaluated by measuring the APTT $(\mathbf{a}, \mathbf{b})$, the PT $(\mathbf{c}, \mathbf{d})$ and the TT $(\mathbf{e}, \mathbf{f})$. Plasma from pigs was incubated with $0.5 \mu \mathrm{g}$ of the antigenic extract $(\mathbf{\square})$ or with PBS as a negative control $(\bullet)$, and the corresponding reagent (APTT, PT or TT). Each point represents the mean of three replicates \pm SD. Significant differences $(p<0.05)$ are marked with an asterisk $\left({ }^{*}\right)$.
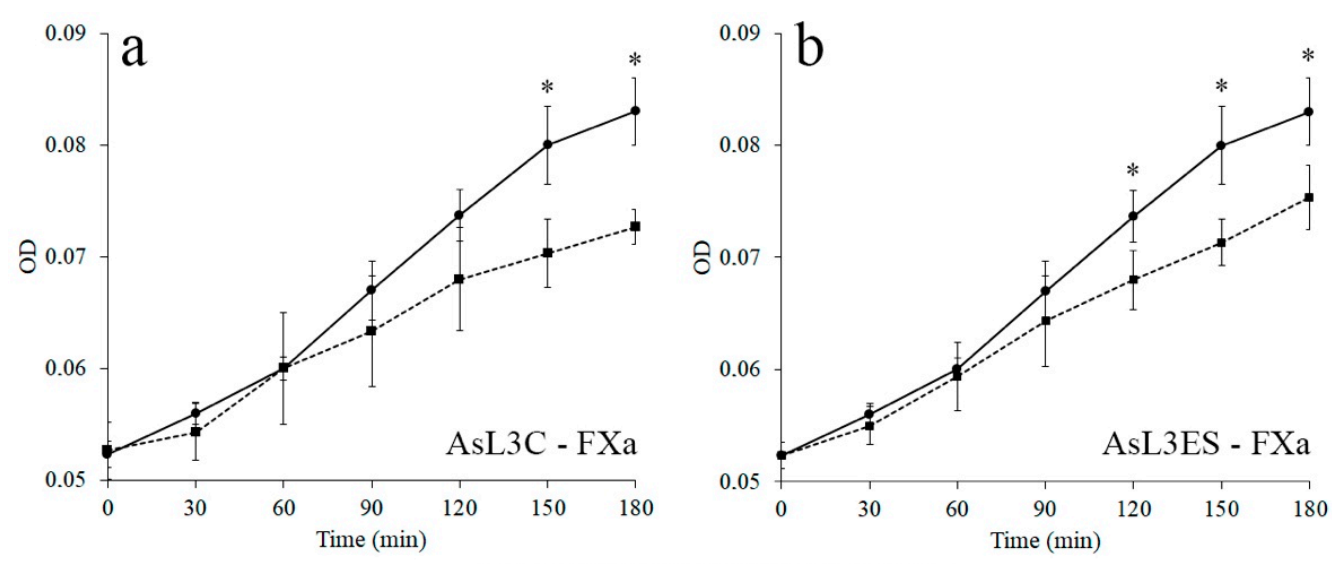

$$
\text { - }
$$

Figure 2. Inhibition of FXa by AsL3C (a) and AsL3ES (b). $0.1 \mu \mathrm{g}$ of the antigenic extract ( $\mathbf{\square})$ were incubated with $4 \mathrm{nM}$ FXa and $800 \mu \mathrm{M}$ S-2765 in a total volume of $100 \mu \mathrm{L}$. The presence of the antigenic extract was replaced by PBS as a negative control in the previous reaction mixtures $(\bullet)$. Each point represents the mean of three replicates \pm SD. Significant differences $(p<0.05)$ are marked with an asterisk $\left(^{*}\right)$. 


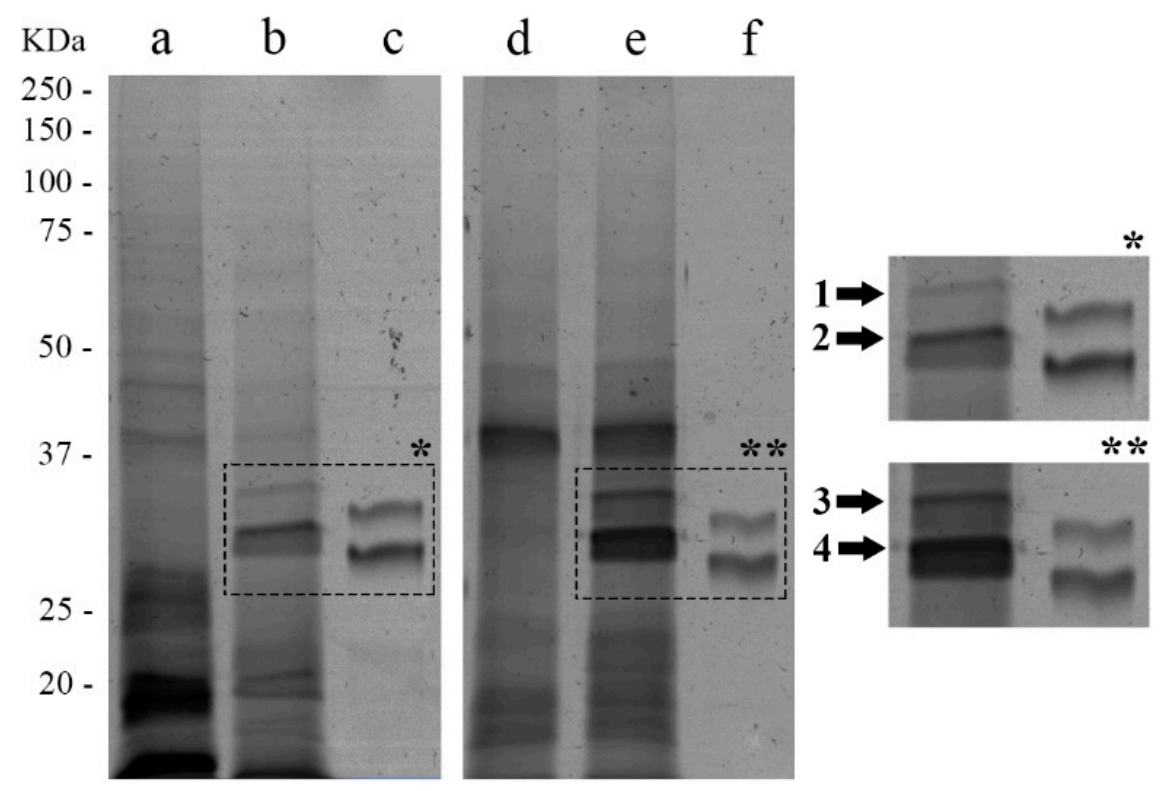

Figure 3. Binding of AsL3C (a-c) and AsL3ES (d-f) to FXa by SDS-PAGE. $10 \mu \mathrm{g}$ of the antigenic extract $(\mathbf{a}, \mathbf{d}), 10 \mu \mathrm{g}$ of the antigenic extract $+1 \mu \mathrm{g}$ of the FXa $(\mathbf{b}, \mathbf{e})$ and $1 \mu \mathrm{g}$ of the FXa $(\mathbf{c}, \mathbf{f})$ were pre-incubated in $5 \mathrm{mM}$ HEPES buffer, $\mathrm{pH}$ 7.4. The reference of molecular weights is indicated on the left. The bands marked with arrows correspond to the FXa in the samples incubated with AsL3C ${ }^{*}$ ) and AsL3ES (**).

\subsection{Identification of Potential Inhibitors of FXa in AsL3C and AsL3ES}

The two bands containing potential FXa-AsL3 protein complexes in the pre-incubated mixtures of the coagulation factor with each antigenic extract (Figure 3) were manually excised from the silver stained SDS-PAGE gels and identified by LC-MS/MS. Among different parasite proteins identified in the analysed bands, three serpins deposited in databases as A. suum proteins were found (Table 1). One of these proteins appeared in AsL3C, another protein derived from AsL3ES and the last one was identified in both extracts. These candidates were identified in the band located in the highest molecular weight in both antigenic extracts. The bands located in the lowest molecular weight did not show any serpin. Homo sapiens coagulation factor $\mathrm{X}$ was found in all analysed bands. All these proteins were identified with a confidence percentage of $99 \%$ according to the equation [ProtScore $=-\log (1-$ (percent confidence $/ 100))]$ in the ProteinPilot. The bioinformatic analyses of the deduced amino-acid sequences of the selected proteins allowed us to identify the cleavage site of the signal peptide and the serpin signature sequence in one and two proteins, respectively. These data, together with the UniProt accession code of the proteins, their description, theoretical molecular weights (MW) and length of the amino-acid sequences are shown in Table 1.

Table 1. Serpins of AsL3C and AsL3ES identified by LC-MS/MS from the analysed bands. All identifications belonged to A. suum proteins deposited in databases. The band numbers correspond to those numbers indicated in Figure 3. Amino-acid, aa.

\begin{tabular}{|c|c|c|c|c|c|c|c|}
\hline $\begin{array}{c}\text { Band } \\
\text { Number }\end{array}$ & $\begin{array}{c}\text { Antigenic } \\
\text { Extract }\end{array}$ & Accession Code & Description & $\begin{array}{l}\text { Theoretical } \\
\text { MW (kDa) }\end{array}$ & $\begin{array}{l}\text { Length } \\
\text { (aa) }\end{array}$ & $\begin{array}{l}\text { Cleavage } \\
\text { Site (aa) }\end{array}$ & $\begin{array}{c}\text { Serpin } \\
\text { Signature (aa) }\end{array}$ \\
\hline 1 & AsL3C & F1L4J8_ASCSU & Serpin B6 & 41.4 & 370 & - & $\begin{array}{c}\text { FIADHPFLFAV } \\
(347-357)\end{array}$ \\
\hline 3 & AsL3ES & F1L040_ASCSU & $\begin{array}{l}\text { Serpin-like } \\
\text { protein }\end{array}$ & 36.7 & 323 & - & $\begin{array}{c}\text { FTADHPFLFAI } \\
(304-314)\end{array}$ \\
\hline 1,3 & $\begin{array}{l}\text { AsL3C, } \\
\text { AsL3ES }\end{array}$ & F1L2I5_ASCSU & Serpin B6 & 42.3 & 373 & $22-23$ & - \\
\hline
\end{tabular}


The three identified serpins were also compared by multiple sequence alignment to the physiological inhibitor of FXa in mammals, the antithrombin III from Sus scrofa domesticus and H. sapiens (accession codes to UniProt: Q7M364_PIG and ANT3_HUMAN, respectively). The results of this analysis revealed identity percentages that ranged between $31.18 \%$ and $36.56 \%$ in the case of S. scrofa domesticus and $29.03 \%$ and $35.42 \%$ for H. sapiens. This analysis was also carried out to compare sequence alignment between the serpin signature domains of F1L4J8_ASCSU and F1L040_ASCSU and the physiological inhibitors of FXa in mammals. The results showed identity percentages of $45.45 \%$ and $54.55 \%$ between serpin signature domains of serpins identified in AsL3C and AsL3ES extracts and those domains of antithrombin III from mammals, respectively (Figure 4).

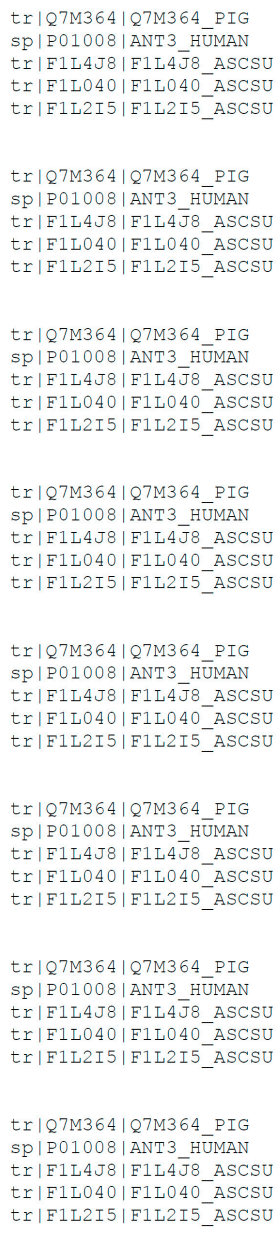

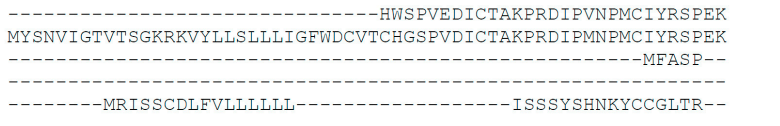

KATEGEGSEQKI PEATNRRVWELSKANSHFATIFYQHLADSKNDNDNIFLSPLSISTAFA KATEDEGSEOKI PEATNRRVWELSKANSRFATTFYOHLADSKNDNDNIFLSPLSISTAFA KATEDEGSEQKIPEATNRRVWE LSKANSR A A IAQANFALDLIKHSIDED---QSSVISPFSVAIALA -

MTKLGACDNTLKQLMEVFKFDTISEKTSDQVHFFFAKLNCRLYRKANKSSELVSANRLFG MTKIGACNDTI MTYAGADGKTRQE MTYAGADGKTKQEMINEALAKGLP----DSEIHEHFAKLVDEL-SKPADGYALSTANRLYI MLVNDTIKOMDVLAGAS---DKEENDHFGKILQEL-SQSRSGYLLSSANKLFI MTYAGAMDNTYKQMNDI LAGGAS----DRE FNEHFSKLLQEL-SQPNKSYKMSS SNKVE I

DKSLTFNETYQE ISEVVYGAKLQPLDFKENAEQSRGI INQWVSNKTEGRITDVIPPEAIN DKSLT FNETYQDISELVYGAKLQPLDFKENAEQSRAAINKWVSNKTEGRITDVIPSEAIN DQRLSLKDAFMS I I KNYAGQLQAADFKQAAI-VANE INTWVESQTNSMIKDLVHPDKIT KKGF S LKE TYLE I IRSVYGGLLEQVDFS QADA-VASE INEWVERQT SSKI TNLVQPEMFD KKGIDLKESYRN I IQTLYGGQLEQVDFSQRIA-A.ANVINDWVANETNSKIKQI IEPYMLP

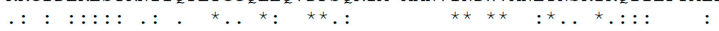

ELTVLVLVNTIYFKGRWKSKFSSENTRKELFYKANGESCSVSMMYQESKFRYRRVAEGTQ ELTVLVLVNTIYFKGLWKSKFS PENTRKELFYKADGESCSASMMYQEGKFRYRVAEGTQ DDSRLILVNAVYFKGDWANKFDEANTAKKLFYTTADRHREVDMMRIKDKFNYVE-DPDWQ DLTRMVLVNAIYFKGLWNIEFTESQTRKAIFYEKEGATRQVDMMSVKANYPHYQ-NEKVQ ELTRMI LVNAVYF SGTWKNI FKKTS TAQKA FYEANGATRAVDMMW INNY F PYYA-NDKVQ

VLELPFKGDDITMVLILPKLEKSLAKVEQELTPEVLQEWLDELADTLLVVHMPRFRIEDS VLELPFKGDDITMVLILPKPEKSLAKVEKELTPEVLQEWLDELEEMMLVVHMPRFRIEDG TLGLPYKNGEVYMYFFLPKERFGLGKOLKVIDGQRIMEMIGDCDNIEVEVELPKFKLEKK VLGLPYKNKEVYMYVFLPREKYGLAAFEESLNGQQMLEMI RNAS SNEVIVELPKFKLEKR VLGLPYKNNEVYMYVELPREKYGLAALEESLSGQMLEMI HNTTRRQVVVELPKFKLKER

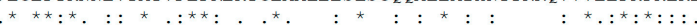

FSVKERLQDMGLEDLFI PEKAKLPGIVAEGRDDLYVSDAFHKAFLEVNEEGSEAAASTAI FSLKEQLQDMGLVDLFSPEKSKLPGIVAEGRDDLYVSDAFHKAF LEVNEEGSEAAASTAV LELVETLKKLGIEEAFSQASADFSGISD FSLVSALAKLGI I DAFGD-SANFSGISD---VPLKISNVI HKAFI EVNEKGTEAAAATAV FNVVNPLKKLGITDAFGD-SANFNGISD---VPLKISDI I HRAFIEVDENGTKAGIAKTK

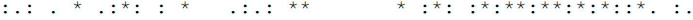

GIAGRS-LNPAR--VTFKANRPFLVLIREVALNTII FMGRVANPC-- 431 VIAGRS-LNPNR--VTFKANRPFLVEIREVPLNTII FMGRVANPCVK 464 -VVKDSTILFIGQFA----- 370 LMIRKTSVQIKRRPIRETADHPFLFA--IVKGNTILFI--------- 323

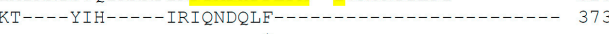

\begin{tabular}{l|ll}
$\begin{array}{c}\text { Identity (8) } \\
\text { Whole sequence }\end{array}$ & Q7M364_PIG & ANT3_HUMAN \\
\hline Q7M364_PIG & - & - \\
ANT3_HUMAN & - & - \\
F1L4J8_ASCSU & 35.15 & 35.42 \\
F1L040_ASCSU & 36.56 & 35.00 \\
FIL2I5_ASCSU & 31.18 & 29.03
\end{tabular}

\begin{tabular}{l|ll}
$\begin{array}{l}\text { Identity (8) } \\
\text { Serpin signature }\end{array}$ & Q7M364_PIG & \multicolumn{1}{l}{ ANT3_HUMAN } \\
\hline Q7M364_PIG & - & - \\
ANT3_HUMAN & - & - \\
F1L4J8_ASCSU & 45.45 & 45.45 \\
F1L040_ASCSU & 54.55 & 54.55 \\
F1I2I5_ASCSU & - & -
\end{tabular}

Figure 4. Alignment of the AsL3C and AsL3ES serpins (F1L4J8_ASCSU, F1L040_ASCSU and F1L2I5_ASCSU) identified by LC-MS/MS with the antithrombin III from S. scrofa domesticus (Q7M364_PIG) and H. sapiens (ANT3_HUMAN). The amino-acids conserved in all sequences are labelled with asterisks while the conservative and semiconservative substitutions are respectively labelled with two and one point. The identity percentage of both the whole sequences and the serpin signature domains between AsL3 serpins and pig and human antithrombin III is indicated in the tables below. The serpin signature sequences are highlighted in yellow. 


\section{Discussion}

Host-parasite relationships have evolved as a successful mechanism, allowing parasites to confront and evade the response of their hosts as well as to facilitate their adaptation to the host tissues. These strategies of manipulation need to be properly regulated, especially in some tissues such as vascular locations, where blood parasites are exposed to multiple aggression mechanisms from the host, among these are the generation of thromboembolisms [12,29]. In this context, the ability of some parasites to alter the host coagulation cascade has been widely studied $[30,31]$. While A. suum is considered to be an intestinal parasite due to its definitive location, its infective L3 stage undergoes an extensive migration through the host bloodstream that begins and ends in the same location [5]. In this regard, tissue migration by parasitic nematode larvae has been proposed as a selectively advantageous strategy facilitating their establishment in the host [32]. For this reason, the aim of this work was to study the ability of AsL3 to interact with the host coagulation cascade as a potential survival mechanism through the use of parasite extracts containing cuticle and excretory/secretory proteins representing the host-parasite interface.

The results obtained in the present study revealed that AsL3C and AsL3ES inhibited the intrinsic, extrinsic and/or common pathways of the coagulation cascade before the transformation of fibrinogen into fibrin, since the APTT and PT assays were significantly altered in the presence of both antigenic extracts, but no significant change was found in the TT assay. These results correlate with those obtained in other studies using similar methodologies for both helminth and arthropod parasites [33-37] as well as reinforce the studies developed with the adult worms of $A$. suum and its closely related species A. lumbricoides during the 1980s and 1990s [38,39].

Specifically, the disruption of the coagulation cascade by parasites has been demonstrated to be influenced by the inhibitory activity of parasite antigens on the host coagulation factors [40-43]. In this sense, our data showed that both antigenic extracts, AsL3C and AsL3ES, possessed inhibitory activity against FXa. Due to its pivotal role in thrombin formation, FXa is one of the most studied coagulation factors in host-parasite relationships, being the main target of numerous anticoagulant molecules identified in parasites $[24,37,44-47]$. Furthermore, FXa has been proposed as a promising target for the development of new anticoagulant agents [48], among which a number of anticoagulant peptides from some species of ticks and hookworms have already been assayed [49].

Antithrombin, the main physiological inhibitor of FXa and other coagulation factors in mammals, belongs to the group of serpins, and thus parasite serpins have been widely suggested to be responsible for regulating the coagulation cascade of their hosts $[9,16,50-53]$. The inhibitory mechanism of serpins entails the formation of an irreversible complex between these enzymes and their target proteins, hence this complex can be studied by SDS-PAGE [17]. According to this, our results revealed the formation of potential inhibitory complexes between each of the studied antigenic extracts (AsL3C/AsL3ES) and FXa, which correlates with other similar studies [37,54]. The subsequent analysis by LC-MS/MS of these complexes allowed us to identify three $A$. suum serpins as potential candidates to inhibit FXa. It is worth mentioning that, in addition to their role in disrupting coagulation cascade, helminth serpins have also been related to other important survival mechanisms such as the modulation of inflammation and the host immune system [55-57]. In regards to porcine ascariosis, complexes formed between $A$. suum serpins and host proteases have been postulated as a mechanism to mask the larvae surface in order to evade the host immune response during their migration [58]. In addition, serpins have also been related to A. suum protection from digestive degradation by the host proteolytic enzymes [58]. Despite their important role in parasite survival, some data suggest that serpins released by parasites could be detected by the host immune system because of their high immunogenic potential, so they have been proposed as interesting targets for the development of novel vaccination strategies [16]. Finally, the multiple sequence alignment carried out to compare AsL3C and AsL3ES identified serpins with pig and human antithrombin showed low homology between nematode and mammalian serpins. However, the similarity was notably 
higher when the serpin signature sequences were compared separately. These results are in accordance with those obtained for other nematode parasites [37] and the statement postulated by Zang and Maizels [16] that suggests that nematode and mammalian serpins have low overall homology, but they are highly conserved at most of the key amino-acid residues necessary to maintain the structure and function of the protein such as the serpin signature.

The fact that different parasites infecting different host species develop similar strategies to regulate the coagulation cascade of their hosts denotes their importance and evolutionary conservation. For AsL3, blood clots could constitute a barrier to migrate through the host bloodstream and tissues, and moreover, to establish in the host since the activation of coagulation is involved in the immune response during infections [59]. The anticoagulant potential of AsL3 could limit thrombin production and consequently fibrin generation, avoiding blood clots formation. This mechanism could occur in the AsL3 immediate intravascular habitat or at a systemic level, since similar results were obtained in this study by both their cuticle and excretory/secretory products. Therefore, this strategy could help the parasite to migrate, evade the host immune system and survive, as it has been postulated for other nematode and trematode parasites $[31,35,37,60]$. In addition, coagulation inhibition by AsL3 could contribute to aggravate the pathological processes produced in the infected pigs. In this sense, this phenomenon could be responsible for producing bleedings and haemorrhagic lesions that emerge in the intestinal mucosa, liver and lungs as a result of larvae penetration and migration $[4,8,61,62]$. These lesions not only affect pig welfare, but they also cause important economic losses for the swine industry due to condemnation or downgrading of damaged organs [4].

All these results are in line with those obtained in the previous study, which showed the pro-fibrinolytic potential of AsL3 [18]. The present work reinforces the idea that AsL3 could modulate the haemostatic system of their host for their own benefit, not only through the dissolution of blood clots, but also preventing their formation. In addition, the results obtained in the present study could contribute to expand the knowledge on the hostparasite relationships in human ascariosis caused by A. lumbricoides, since this species has a similar life-cycle to A. suum [5] and growing studies are pointing out that hybridisation and cross-transmission between both species occur [63-66].

\section{Conclusions}

To our knowledge, we demonstrate for the first time the ability of AsL3 to inhibit the coagulation cascade, at least at the FXa level, by the anticoagulant activity of both their cuticle and excretory/secretory antigenic extracts, as well as identified AsL3 serpins as potential inhibitors of FXa. The inhibition of blood clots formation by the parasite could be an important mechanism to migrate, establish and survive in the host. The diverse strategies of AsL3 to interact with the haemostatic system of the pig suggest the importance of the regulation of blood clots formation for the parasite and the complexity of host-parasite relationships in porcine ascariosis. Thus, knowing these relationships in the early larval stage is of paramount importance to found new control strategies such as vaccination. Future studies could identify and characterise these anticoagulant molecules, which potentially constitute new targets to the control of ascariosis, and moreover, a source of new antithrombotic agents for human therapy.

Author Contributions: Conceptualization, J.G.-M.; methodology, A.D.; resources, F.S. and R.M.; data curation, A.D., F.S. and J.G.-M.; writing-original draft preparation, A.D.; writing-editing, J.G.-M.; writing-review, F.S. and R.M.; funding acquisition, F.S. and R.M. All authors have read and agreed to the published version of the manuscript.

Funding: This research was funded by the Centro para el Desarrollo Tecnológico Industrial (CDTI), grant number IDI-2016414. A.D. is supported by a doctoral fellowship from the University of Salamanca, co-funded by Banco Santander. J.G.-M. is supported by the "Juan de la Cierva-Incorporación" program (IJC2018-036660-I) of the Ministerio de Ciencia, Innovación y Universidades (MCIU). 
Institutional Review Board Statement: The study did not require consent or ethical approval. Permission to obtain the samples was granted from the veterinary personnel of Cooperative Society "Chacinera Albercana" (Salamanca, Spain).

Data Availability Statement: Not Applicable.

Acknowledgments: The authors acknowledge Cooperative Society "Chacinera Albercana" (Salamanca, Spain) for providing them the adult female worms of A. suum and the blood samples from pigs. The proteomic analysis was performed in the proteomics facility of SCSIE from the University of Valencia that belongs to ProteoRed PRB3 and is supported by grant PT17/0019 of the PE I+D+i 2013-2016, funded by ISCIII and ERDF.

Conflicts of Interest: The authors declare no conflict of interest. The funders had no role in the design of the study; in the collection, analysis, or interpretation of data; in the writing of the manuscript, or in the decision to publish the results.

\section{References}

1. Larson, G.; Albarella, U.; Dobney, K.; Rowley-Conwy, P.; Schibler, J.; Tresset, A.; Vigne, J.D.; Edwards, C.J.; Schlumbaum, A.; Dinu, A.; et al. Ancient DNA, pig domestication, and the spread of the Neolithic into Europe. Proc. Natl. Acad. Sci. USA 2007, 104, 15276-15281. [CrossRef]

2. Food and Agriculture Organization of the United Nations. Available online: http://www.fao.org/ag/againfo/themes/en/ animal_production.html (accessed on 27 October 2020).

3. Eurostat. Available online: https://ec.europa.eu/eurostat/data/database (accessed on 27 October 2020).

4. Thamsborg, S.M.; Nejsum, P.; Mejer, H. Impact of Ascaris suum in Livestock. In Ascaris: The Neglected Parasite, 1st ed.; Holland, C., Ed.; Academic Press: Cambridge, MA, USA; Elsevier: Amsterdam, The Netherlands, 2013; pp. 363-381. [CrossRef]

5. Dold, C.; Holland, C.V. Ascaris and ascariasis. Microbes Infect. 2011, 13, 632-637. [CrossRef]

6. Vlaminck, J.; Geldhof, P. Diagnosis and Control of Ascariasis in Pigs. In Ascaris: The Neglected Parasite, 1st ed.; Holland, C., Ed.; Academic Press: Cambridge, MA, USA; Elsevier: Amsterdam, The Netherlands, 2013; pp. 395-425. [CrossRef]

7. Jex, A.R.; Liu, S.; Li, B.; Young, N.D.; Hall, R.S.; Li, Y.; Yang, L.; Zeng, N.; Xu, X.; Xiong, Z.; et al. Ascaris suum draft genome. Nature 2011, 479, 529-533. [CrossRef] [PubMed]

8. Holland, C.V.; Behnke, J.M.; Dold, C. Larval Ascariasis: Impact, Significance, and Model Organisms. In Ascaris: The Neglected Parasite, 1st ed.; Holland, C., Ed.; Academic Press: Cambridge, MA, USA; Elsevier: Amsterdam, The Netherlands, 2013; pp. 107-125. [CrossRef]

9. Knox, D.P. Proteinase inhibitors and helminth parasite infection. Parasite Immunol. 2007, 29, 57-71. [CrossRef]

10. Molehin, A.J.; Gobert, G.N.; McManus, D.P. Serine protease inhibitors of parasitic helminths. Parasitology 2012, 139, 681-695. [CrossRef] [PubMed]

11. Figuera, L.; Gómez-Arreaza, A.; Avilán, L. Parasitism in optima forma: Exploiting the host fibrinolytic system for invasion. Acta Trop. 2013, 128, 116-123. [CrossRef] [PubMed]

12. González-Miguel, J.; Siles-Lucas, M.; Kartashev, V.; Morchón, R.; Simón, F. Plasmin in Parasitic Chronic Infections: Friend or Foe? Trends Parasitol. 2016, 32, 325-335. [CrossRef]

13. Adams, R.L.C.; Bird, R.J. Review article: Coagulation cascade and therapeutics update: Relevance to nephrology. Part 1: Overview of coagulation, thrombophilias and history of anticoagulants. Nephrology (Carlton) 2009, 14, 462-470. [CrossRef] [PubMed]

14. Smith, S.A.; Travers, R.J.; Morrissey, J.H. How it all starts: Initiation of the clotting cascade. Crit. Rev. Biochem. Mol. Biol. 2015, 50, 326-336. [CrossRef]

15. Butenas, S.; Mann, K.G. Blood Coagulation. Biochemistry (Mosc.) 2002, 67, 3-12. [CrossRef]

16. Zang, X.; Maizels, R.M. Serine proteinase inhibitors from nematodes and the arms race between host and pathogen. Trends Biochem. Sci. 2001, 26, 191-197. [CrossRef]

17. Gettins, P.G.W. Serpin Structure, Mechanism, and Function. Chem. Rev. 2002, 102, 4751-4803. [CrossRef] [PubMed]

18. Diosdado, A.; Simón, F.; Morchón, R.; González-Miguel, J. Pro-fibrinolytic potential of the third larval stage of Ascaris suum as a possible mechanism facilitating its migration through the host tissues. Parasit. Vectors 2020, 13, 203. [CrossRef]

19. Vlaminck, J.; Masure, D.; Wang, T.; Nejsum, P.; Hokke, C.H.; Geldhof, P. A Phosphorylcholine-Containing Glycolipid-like Antigen Present on the Surface of Infective Stage Larvae of Ascaris spp. Is a Major Antibody Target in Infected Pigs and Humans. PLoS Negl. Trop. Dis. 2016, 10, e0005166. [CrossRef]

20. Urban, J.F., Jr.; Douvres, F.W.; Tromba, F.G. A Rapid Method for Hatching Ascaris suum Eggs In Vitro. Proc. Helminthol. Soc. Wash. 1981, 48, 241-243.

21. Wedrychowicz, H.; Holmes, P.H.; Bairden, K.; Tait, A. Surface and excretory/secretory antigens of fourth-stage larvae and adult Ostertagia circumcincta. Vet. Parasitol. 1994, 53, 117-132. [CrossRef]

22. González-Miguel, J.; Morchón, R.; Mellado, I.; Carretón, E.; Montoya-Alonso, J.A.; Simón, F. Excretory/secretory antigens from Dirofilaria immitis adult worms interact with the host fibrinolytic system involving the vascular endothelium. Mol. Biochem. Parasitol. 2012, 181, 134-140. [CrossRef] 
23. Maizels, R.M.; Blaxter, M.L.; Robertson, B.D.; Selkirk, M.E. Parasite Antigens, Parasite Genes: A Laboratory Manual for Molecular Parasitology, 1st ed.; Cambridge University Press: Cambridge, UK, 1991.

24. Gan, W.; Deng, L.; Yang, C.; He, Q.; Hu, J.; Yin, H.; Jin, X.; Lu, C.; Wu, Y.; Peng, L. An anticoagulant peptide from the human hookworm, Ancylostoma duodenale that inhibits coagulation factors Xa and XIa. FEBS Lett. 2009, 583, 1976-1980. [CrossRef] [PubMed]

25. Fonseca, F.P.P.; Ike, P.T.L.; Assis, D.M.; Icimoto, M.Y.; Juliano, M.A.; Juliano, L.; Puzer, L.; Henrique-Silva, F. Leviserpin: A Serine Peptidase Inhibitor (Serpin) from the Sugarcane Weevil Sphenophorus levis. Protein J. 2011, 30, 404-412. [CrossRef] [PubMed]

26. Shevchenko, A.; Jensen, O.N.; Podtelejnikov, A.V.; Sagliocco, F.; Wilm, M.; Vorm, O.; Mortensen, P.; Shevchenko, A.; Boucherie, H.; Mann, M. Linking genome and proteome by mass spectrometry: Large-scale identification of yeast proteins from two dimensional gels. Proc. Natl. Acad. Sci. USA 1996, 93, 14440-14445. [CrossRef]

27. Shilov, I.V.; Seymour, S.L.; Patel, A.A.; Loboda, A.; Tang, W.H.; Keating, S.P.; Hunter, C.L.; Nuwaysir, L.M.; Schaeffer, D.A. The Paragon Algorithm, a next generation search engine that uses sequence temperature values and feature probabilities to identify peptides from tandem mass spectra. Mol. Cell Proteom. 2007, 6, 1638-1655. [CrossRef] [PubMed]

28. Bendtsen, J.D.; Nielsen, H.; von Heijne, G.; Brunak, S. Improved prediction of signal peptides: SignalP 3.0. J. Mol. Biol. 2004, 340, 783-795. [CrossRef] [PubMed]

29. Poulin, R. Evolutionary Ecology of Parasites, 2nd ed.; Princeton University Press: Princeton, NJ, USA, 2007.

30. Stanssens, P.; Bergum, P.W.; Gansemans, Y.; Jespers, L.; Laroche, Y.; Huang, S.; Maki, S.; Messens, J.; Lauwereys, M.; Cappello, M.; et al. Anticoagulant repertoire of the hookworm Ancylostoma caninum. Proc. Natl. Acad. Sci. USA 1996, 93, 2149-2154. [CrossRef]

31. Mebius, M.M.; van Genderen, P.J.J.; Urbanus, R.T.; Tielens, A.G.M.; de Groot, P.G.; van Hellemond, J.J. Interference with the Host Haemostatic System by Schistosomes. PLoS Pathog. 2013, 9, e1003781. [CrossRef]

32. Read, A.F.; Skorping, A. The evolution of tissue migration by parasitic nematode larvae. Parasitology 1995, 111, 359-371. [CrossRef]

33. Perteguer, M.J.; Raposo, R.; Cuéllar, C. In Vitro Study on the Effect of Larval Excretory/Secretory Products and Crude Extracts from Anisakis simplex on Blood Coagulation. Int. J. Parasitol. 1996, 26, 105-108. [CrossRef]

34. Stark, K.R.; James, A.A. Anticoagulants in Vector Arthropods. Parasitol. Today 1996, 12, 430-437. [CrossRef]

35. Joachim, A.; Ali, S.F.; Daugschies, A. Fasciola hepatica alters coagulation parameters in sheep plasma in vivo and in vitro. Parasitol. Res. 2003, 89, 53-58. [CrossRef]

36. Mieszczanek, J.; Harrison, L.M.; Vlasuk, G.P.; Cappello, M. Anticoagulant peptides from Ancylostoma caninum are immunologically distinct and localize to separate structures within the adult hookworm. Mol. Biochem. Parasitol. 2004, 133, 319-323. [CrossRef]

37. Diosdado, A.; Simón, F.; Morchón, R.; González-Miguel, J. Dirofilaria immitis possesses molecules with anticoagulant properties in its excretory/secretory antigens. Parasitology 2020, 147, 559-565. [CrossRef] [PubMed]

38. Crawford, G.P.M.; Howse, D.J.; Grove, D.I. Inhibition of human blood clotting by extracts of Ascaris suum. J. Parasitol. 1982, 68, 1044-1047. [CrossRef] [PubMed]

39. Malla, N.; Sofi, B.A.; Ganguly, N.K.; Mahajan, R.C. In vitro effect of larval stages of Ascaris lumbricoides on human blood clotting. J. Helminthol. 1991, 65, 133-140. [CrossRef]

40. Tsang, V.C.W.; Damian, R.T. Demonstration and Mode of Action of an Inhibitor for Activated Hageman Factor (Factor XIIa) of the Intrinsic Blood Coagulation Pathway from Schistosoma mansoni. Blood 1977, 49, 619-633. [CrossRef] [PubMed]

41. Foster, C.B.; Flanigan, T.P.; Kazura, J.W.; Dumenco, L.L.; Ratnoff, O.D. Inhibition of the activation of Hageman factor (factor XII) and of platelet aggregation by extracts of Brugia malayi microfilariae. J. Lab. Clin. Med. 1991, 117, 344-352.

42. Campos, I.T.N.; Tanaka-Azevedo, A.M.; Tanaka, A.S. Identification and characterization of a novel factor XIIa inhibitor in the hematophagous insect, Triatoma infestans (Hemiptera: Reduviidae). FEBS Lett. 2004, 577, 512-516. [CrossRef] [PubMed]

43. Deng, L.; He, Q.; Kang, T.; Yin, H.; Jin, X.; Li, H.; Gan, W.; Yang, C.; Hu, J.; Wu, Y.; et al. Identification of an anticoagulant peptide that inhibits both fXIa and fVIIa/tissue factor from the blood-feeding nematode Ancylostoma caninum. Biochem. Biophys. Res. Commun. 2010, 392, 155-159. [CrossRef]

44. Cappello, M.; Vlasuk, G.P.; Bergum, P.W.; Huang, S.; Hotez, P.J. Ancylostoma caninum anticoagulant peptide: A hookworm-derived inhibitor of human coagulation factor Xa. Proc. Natl. Acad. Sci. USA 1995, 92, 6152-6156. [CrossRef]

45. Ibrahim, M.A.; Ghazy, A.H.M.; Maharem, T.M.; Khalil, M.I. Factor Xa (FXa) inhibitor from the nymphs of the camel tick Hyalomma dromedarii. Comp. Biochem. Physiol. B Biochem. Mol. Biol. 2001, 130, 501-512. [CrossRef]

46. Harrison, L.M.; Nerlinger, A.; Bungiro, R.D.; Córdova, J.L.; Kuzmic, P.; Cappello, M. Molecular Characterization of Ancylostoma Inhibitors of Coagulation Factor Xa. Hookworm anticoagulant activity in vitro predicts parasite bloodfeeding in vivo. J. Biol. Chem. 2002, 277, 6223-6229. [CrossRef] [PubMed]

47. Ranasinghe, S.L.; Fischer, K.; Gobert, G.N.; McManus, D.P. A novel coagulation inhibitor from Schistosoma japonicum. Parasitology 2015, 142, 1663-1672. [CrossRef]

48. Núñez-Navarro, N.E.; Santana, F.M.; Parra, L.P.; Zacconi, F.C. Surfing the Blood Coagulation Cascade: Insight into the Vital Factor Xa. Curr. Med. Chem. 2019, 26, 3175-3200. [CrossRef]

49. Spencer, F.A.; Becker, R.C. Novel Inhibitors of Factor X for Use in Cardiovascular Diseases. Curr. Cardiol. Rep. 2000, 2, 395-404. [CrossRef] [PubMed]

50. Blanton, R.E.; Licate, L.S.; Aman, R.A. Characterization of a native and recombinant Schistosoma haematobium serine protease inhibitor gene product. Mol. Biochem. Parasitol. 1994, 63, 1-11. [CrossRef] 
51. Rawlings, N.D.; Tolle, D.P.; Barrett, A.J. Evolutionary families of peptidase inhibitors. Biochem. J. 2004, 378, 705-716. [CrossRef] [PubMed]

52. Yi, D.; Xu, L.; Yan, R.; Li, X. Haemonchus contortus: Cloning and characterization of serpin. Exp. Parasitol. 2010, 125, 363-370. [CrossRef] [PubMed]

53. Valdivieso, E.; Perteguer, M.J.; Hurtado, C.; Campioli, P.; Rodríguez, E.; Saborido, A.; Martínez-Sernández, V.; Gómez-Puertas, P.; Ubeira, F.M.; Gárate, T. ANISERP: A new serpin from the parasite Anisakis simplex. Parasit. Vectors 2015, 8, 399. [CrossRef]

54. Francischetti, I.M.B.; Valenzuela, J.G.; Andersen, J.F.; Mather, T.N.; Ribeiro, J.M.C. Ixolaris, a novel recombinant tissue factor pathway inhibitor (TFPI) from the salivary gland of the tick, Ixodes scapularis: Identification of factor X and factor Xa as scaffolds for the inhibition of factor VIIa/tissue factor complex. Blood 2002, 99, 3602-3612. [CrossRef]

55. Ghendler, Y.; Arnon, R.; Fishelson, Z. Schistosoma mansoni: Isolation and Characterization of Smpi56, a Novel Serine Protease Inhibitor. Exp. Parasitol. 1994, 78, 121-131. [CrossRef] [PubMed]

56. Zang, X.; Yazdanbakhsh, M.; Jiang, H.; Kanost, M.R.; Maizels, R.M. A Novel Serpin Expressed by Blood-Borne Microfilariae of the Parasitic Nematode Brugia malayi Inhibits Human Neutrophil Serine Proteinases. Blood 1999, 94, 1418-1428. [CrossRef]

57. De Marco Verissimo, C.; Jewhurst, H.L.; Tikhonova, I.G.; Urbanus, R.T.; Maule, A.G.; Dalton, J.P.; Cwiklinski, K. Fasciola hepatica serine protease inhibitor family (serpins): Purposely crafted for regulating host proteases. PLoS Negl. Trop. Dis. 2020, 14, e0008510. [CrossRef]

58. Martzen, M.R.; Geise, G.L.; Peanasky, R.J. Ascaris suum: Immunoperoxidase and Fluorescent Probe Analysis of Host Proteases and Parasite Proteinase Inhibitors in Developing Eggs and Second Stage Larvae. Exp. Parasitol. 1986, 61, 138-145. [CrossRef]

59. Antoniak, S. The coagulation system in host defense. Res. Pract. Thromb. Haemost. 2018, 2, 549-557. [CrossRef]

60. Yenbutr, P.; Scott, A.L. Molecular Cloning of a Serine Proteinase Inhibitor from Brugia malayi. Infect. Immun. 1995, 63, 1745-1753. [CrossRef] [PubMed]

61. Pérez, J.; García, P.M.; Mozos, E.; Bautista, M.J.; Carrasco, L. Immunohistochemical Characterization of Hepatic Lesions Associated with Migrating Larvae of Ascaris suum in Pigs. J. Comp. Pathol. 2001, 124, 200-206. [CrossRef]

62. Liljegren, C.H.; Aalbaek, B.; Nielsen, O.L.; Jensen, H.E. Some new aspects of the pathology, pathogenesis, and aetiology of disseminated lung lesions in slaughter pigs. APMIS 2003, 111, 531-538. [CrossRef] [PubMed]

63. Criscione, C.D.; Anderson, J.D.; Sudimack, D.; Peng, W.; Jha, B.; Williams-Blangero, S.; Anderson, T.J.C. Disentangling hybridization and host colonization in parasitic roundworms of humans and pigs. Proc. Biol. Sci. 2007, 274, 2669-2677. [CrossRef]

64. Zhou, C.; Li, M.; Yuan, K.; Hu, N.; Peng, W. Phylogeography of Ascaris lumbricoides and A. suum from China. Parasitol. Res. 2011, 109, 329-338. [CrossRef] [PubMed]

65. Betson, M.; Nejsum, P.; Bendall, R.P.; Deb, R.M.; Stothard, J.R. Molecular Epidemiology of Ascariasis: A Global Perspective on the Transmission Dynamics of Ascaris in People and Pigs. J. Infect. Dis. 2014, 210, 932-941. [CrossRef]

66. Easton, A.; Gao, S.; Lawton, S.P.; Bennuru, S.; Khan, A.; Dahlstrom, E.; Oliveira, R.G.; Kepha, S.; Porcella, S.F.; Webster, J.; et al. Molecular evidence of hybridization between pig and human Ascaris indicates an interbred species complex infecting humans. eLife 2020, 9, e61562. [CrossRef] [PubMed] 